УДК $612.3 ; 591.132$

(C) 2014

Мироненко О. І., кандидат сільськогосподарських наук

Полтавська державна аграрна академія

\title{
ОКРЕМІ СКЛАДОВІ ХІМУСУ ТА ЇХ ОБМІН В ОРГАНІЗМІ ПОРОСЯТ
}

\section{Рецензент - доктор сільськогосподарських наук А. А. Поліщук}

Вивчені особливості травлення у поросят після відлучення, обгрунтовано використання окремих нетрадиційних кормових добавок у раціонах поросят. Досліджено динаміку вмісту мінеральних елементів (кальизію, фосфору, калію, натрію, заліза) та їх обмін y илунково-кишковому тракті поросят під дією окремих кормових добавок. Представлені результати досліджень кормових добавок із сухого мінерального концентрату, ліпроту та ехінацеї пурпурової з точки зору їх впливу на вміст у шлунку, порожній і клубовій кииках.

Ключові слова: поросята, обмін, кальиій, фосфор, калій, натрій, залізо, кормові добавки, раціон, хімус, шлунок, тонкий кишечник, концентрачія, суха речовина.

Постановка проблеми. Сучасні наукові дослідження й виробничі апробації вказують на те, що навіть з урахуванням збалансованості кормових раціонів свиней за життєво важливими показниками, а також їх віку та фізіологічного стану, в умовах промислової технології неможливо обійтися без кормових добавок.

Проблема одержання безпечної продукції 3 посиленням екологічних вимог до інгредієнтів кормових добавок різного походження набула нині особливої актуальності. Вирішенням ії визнаються всілякі кормові добавки, серед яких переважно ті, де використовуються натуральні компоненти.

Заслуговує на увагу кормова добавка, до складу якої входить мінералізована (пластова) вода [6]. За даними Одеського науково-дослідного інституту курортології медичної реабілітації, у мінералізованій (пластовій) воді не виявлено біологічно небезпечних сполук, солей важких металів, радіонуклідів, а також токсичних речовин, шкідливих за відповідних концентрацій для організму тварин $[9,16,17]$.

Саме мінеральним речовинам належить важлива роль у забезпеченні обмінних процесів у організмі та підвищенні ефективності використання концентрованих кормів у тваринництві $[4,6,13]$.

Через погіршення екологічної ситуації помітно знизилася резистентність організму тварин. Це потребує додавання до складу їхнього раціо- ну спеціальних компонентів, які протидіють негативним впливам і підвищують у них імунні властивості. Для розв'язання вказаної потреби використовують кормові й лікувальні властивості багаторічної рослини роду айстрових - ехінацеї пурпурової $[3,18]$. Крім того доцільним $\epsilon$ застосування в раціоні тварин екологічно безпечної високолізинової кормової добавки - ліпроту $[2,7,14]$.

Аналіз останніх досліджень і публікацій, у яких започатковано розв'язання проблеми. У процесі травлення в організмі тварин суттєву роль відіграють макро- і мікроелементи [15]. Існують експериментальні дані з питань фізіології травлення та обміну речовин в організмі поросят $[1,11,19-21]$. Однак, ще недостатньо вивчено проблему впливу природних мінералів, зокрема мінералізованої пластової води у поєднанні з протеїном мікробіологічного походження та стимулюючими рослинними компонентами. Тому виникла проблема вивчення фізіологічних особливостей шлунково-кишкового травлення та обміну речовин у організмі поросят під дією нетрадиційних кормових біологічно активних добавок $[5,6]$.

Мета дослідження - вивчення впливу мінеральних добавок на стан хімусу, динаміки вмісту та обмін мінеральних елементів у хімусі в різних відділах шлунково-кишкового тракту поросят за дії окремих біологічно активних кормових добавок.

Для досягнення цієї мети необхідно було вирішити наступні завдання: визначити вміст сухої речовини, кальцію, фосфору, калію, натрію, заліза в хімусі шлунка, порожньої та клубової кишки.

Матеріали і методика досліджень. Дослідження проводилися на базі лабораторії фізіології відтворення і трансплантації ембріонів, зоохімічного аналізу та експериментальної бази Інституту свинарства ім. О. В. Квасницького УААН.

В експерименті використовували комбікорм, збалансований за обмінною енергією, протеїном та іншими інгредієнтами для поросят дослідних і контрольної груп.

Для тварин дослідних груп даванку комбікорму зменшували на $2 \%$ маси, що за вмістом пере- 


\section{СІЛЬСЬКЕ ГОСПОДАРСТВО. ТВАРИННИЦТВО}

травного протеїну та обмінної енергії відповідає кількості соняшникового шроту.

У досліді використовували одно-, двокомпонентну та комплексну кормову добавку в раціоні дослідних тварин. Поросята першої дослідної групи одержували 2 \% сухого мінерального концентрату (СМК); другої - 1,7\% ліпроту (Л), $0,3 \%$ - ехінацеї пурпурової (ЕП); третьої 0,5 \% СМК, 1,25 \% - Л та 0,25\% ЕП від основного раціону.

Дослідження проводили методом періодів, використовуючи 8 свинок великої білої породи тримісячного віку - аналогів за живою масою. Застосовуючи хірургічні операції, вивчали травлення піддослідних тварин відповідно до методу накладання фістули на шлунок (за В. О. Басовим, 1988) та порожню і клубову кишки (за О. В. Квасницьким, 1951).

Згідно 3 прийнятою методикою проведення фізіологічних досліджень, було сформовано три дослідних і контрольну групи, по дві голови у кожній. Дослід мав 3 періоди: підготовчий 6 днів, перехідний - 10 днів і обліковий - 3 дні. Впродовж облікового періоду щодня проводили відбір проб хімусу з фістул шлунка, порожньої та клубової кишок $з$ інтервалами 2 год., а саме: голодна проба - за 1 год. до годівлі, через 2, 4 та
6 год. після годівлі [12].

У фізіологічних обмінних дослідах вивчали вплив мінеральних добавок на обмін кальцію, фосфору, калію, натрію та заліза в організмі молодняку свиней. Дослід проводився за методикою М. А. Коваленка (1977).

Вивчення досліджуваних мінералів проводили згідно з існуючими методиками [8].

Результати досліджень. Аналізуючи результати досліджень, враховували такі чинники: вміст сухої речовини, вміст мінеральних елементів у хімусі різних відділів шлунково-кишкового тракту тварин, динаміку їх під час голодної проби і впродовж травлення спожитого корму, а також вплив спеціальних кормових добавок.

Загальна кількість сухої речовини в хімусі шлунка поросят піддослідних груп знаходилась у межах від 13,09 до 19,56 \% (табл. 1). Не встановлено істотної різниці за цим показником між тваринами дослідних i контрольної груп. Спостерігається тенденція у зміні величин за вмістом сухої речовини за інтервалами відбору проб хімусу. Найменша концентрація іiі становить у період одержання голодної проби, найбільша через дві години після прийняття корму ( $\mathrm{p} \leq 0,001)$, а далі цей показник знижується, хоча й не перевищує рівня голодної проби.

\section{1. Вміст сухої речовини в хімусі илунка, порожньой та клубової кишок піддослідних поросят, \%, $M \pm m, n=12$}

\begin{tabular}{|c|c|c|c|c|}
\hline \multirow{3}{*}{$\begin{array}{c}\text { Відбір через різні } \\
\text { інтервали, год. }\end{array}$} & \multicolumn{4}{|c|}{ Групи } \\
\hline & \multirow{2}{*}{ контрольна } & \multicolumn{3}{|c|}{ дослідні } \\
\hline & & I & II & III \\
\hline \multicolumn{5}{|c|}{ Шлунок } \\
\hline 0 & $14,89 \pm 0,30$ & $15,43 \pm 0,26$ & $15,89 \pm 0,28$ & $16,37 \pm 0,19$ \\
\hline 2 & $18,07 \pm 0,35$ & $18,59 \pm 0,23$ & $19,15 \pm 0,33$ & $19,56 \pm 0,12$ \\
\hline 4 & $14,60 \pm 0,18$ & $14,94 \pm 0,17$ & $15,39 \pm 0,18$ & $15,85 \pm 0,16$ \\
\hline 6 & $13,09 \pm 0,15$ & $13,41 \pm 0,19$ & $13,18 \pm 0,16$ & $14,22 \pm 0,20$ \\
\hline \multicolumn{5}{|c|}{ Порожня кишка } \\
\hline 0 & $6,12 \pm 0,21$ & $6,89 \pm 0,15$ & $7,25 \pm 0,11$ & $7,62 \pm 0,17$ \\
\hline 2 & $8,39 \pm 0,19$ & $9,34 \pm 0,11$ & $9,49 \pm 0,09 * * *$ & $9,86 \pm 0,08 * * *$ \\
\hline 4 & $6,48 \pm 0,24$ & $6,95 \pm 0,10$ & $7,39 \pm 0,18$ & $7,61 \pm 0,13$ \\
\hline 6 & $5,10 \pm 0,26$ & $5,83 \pm 0,16$ & $6,72 \pm 0,14$ & $6,94 \pm 0,12$ \\
\hline \multicolumn{5}{|c|}{ Клубова кишка } \\
\hline 0 & $8,33 \pm 0,16$ & $8,58 \pm 0,11$ & $8,84 \pm 0,15$ & $9,16 \pm 0,16$ \\
\hline 2 & $10,53 \pm 0,11$ & $10,84 \pm 0,15$ & $11,16 \pm 0,09$ & $11,61 \pm 0,12$ \\
\hline 4 & $11,04 \pm 0,16$ & $11,37 \pm 0,19$ & $11,73 \pm 0,18$ & $12,18 \pm 0,18$ \\
\hline 6 & $12,45 \pm 0,12$ & $10,67 \pm 0,12$ & $11,02 \pm 0,13$ & $11,47 \pm 0,13$ \\
\hline
\end{tabular}

Примітка: інтервали: 0 - голодна проба, 2, 4, 6 - через 2, 4 та 6 год. після прийняття корму, 2n - кількість проб; *** - p $\leq 0,001$ - різниця вірогідності порівняно з контролем. 


\section{СІЛЬСЬКЕ ГОСПОДАРСТВО. ТВАРИННИЦТВО}

Порівняно з вмістом сухої речовини в пробі шлунка поросят дослідних і контрольної груп вірогідної різниці не встановлено. Вміст сухої речовини в хімусі порожньої кишки (порівняно зі шлунком) зменшується до 5,10-9,86\%. Концентрація сухої речовини в хімусі клубової кишки була вищою в порівняні 3 порожньою й становила 8,33-12,18\%.

У цілому виявлено значне коливання показників між найменшими і найбільшими концентраціями: кальцію, фосфору та заліза - майже вдвічі, а калію і натрію - утричі (табл. 2). Незважаю- чи на це, простежується відповідна закономірність. Так, у контрольній групі впродовж дослідного періоду за сумарною концентрацією мінеральних елементів у хімусі між окремими відділами травного тракту встановлено істотну різницю. Порівняно 3 показниками хімусу шлунка: у порожній кишці зменшується вміст кальцію на 35,43 ( $\mathrm{p} \leq 0,01)$ заліза $23,21 \%$ (p $\leq 0,001)$, а фосфору і натрію збільшується на $34,49(\mathrm{p} \leq 0,01)$ і $35,55 \%(\mathrm{p} \leq 0,01)$ відповідно; у клубовій кишці достовірно знизилася кількість кальцію - 58,31 (p $\leq 0,001)$ та фосфору - 60,47\% ( $\mathrm{p} \leq 0,001)$, а калію підвищилася на 28,84\% (p $\leq 0,05)$.

\section{2. Динаміка вмісту мінеральних елементів у хімусі илунково-кишкового тракту піддослідних тварин $M \pm m, n \pm 20$}

\begin{tabular}{|c|c|c|c|c|c|}
\hline \multirow{3}{*}{$\begin{array}{c}\text { Досліджувані } \\
\text { елементи }\end{array}$} & \multirow{3}{*}{$\begin{array}{c}\text { Коливання вмісту } \\
\text { інгредієнтів }\end{array}$} & \multicolumn{4}{|c|}{ Групи } \\
\hline & & \multirow{2}{*}{ контрольна } & \multicolumn{3}{|c|}{ дослідні } \\
\hline & & & I & II & III \\
\hline \multicolumn{6}{|c|}{ Шлунок } \\
\hline Кальцій & $93,75-200,75$ & $\begin{array}{l}129,11 \\
\pm 11,71\end{array}$ & $\begin{array}{l}149,53 \\
\pm 13,47\end{array}$ & $\begin{array}{l}153,00 \\
\pm 9,52\end{array}$ & $\begin{array}{l}162,40 \\
\pm 13,51\end{array}$ \\
\hline Фосфор & $93,02-193,15$ & $\begin{array}{l}132,37 \\
\pm 10,46\end{array}$ & $\begin{array}{l}145,02 \\
\pm 11,55\end{array}$ & $\begin{array}{l}144,70 \\
\pm 10,17\end{array}$ & $\begin{array}{l}151,81 \\
\pm 10,84\end{array}$ \\
\hline Калій & $70,40-231,68$ & $\begin{array}{c}115,8 \\
\pm 10,75\end{array}$ & $\begin{array}{l}139,26 \\
\pm 12,29\end{array}$ & $\begin{array}{l}137,81 \\
\pm 11,26\end{array}$ & $\begin{array}{l}149,45 \\
\pm 8,96^{*}\end{array}$ \\
\hline Натрій & $71,77-271,44$ & $\begin{array}{l}150,47 \\
\pm 11,15\end{array}$ & $\begin{array}{l}180,69 \\
\pm 9,87\end{array}$ & $\begin{array}{l}174,36 \\
\pm 9,79\end{array}$ & $\begin{array}{l}190,31 \\
\pm 10,22\end{array}$ \\
\hline Залізо & $602,13-1069,05$ & $\begin{array}{r}774,28 \\
\pm 28,52 \\
\end{array}$ & $\begin{array}{l}844,25 \\
\pm 32,74 \\
\end{array}$ & $\begin{array}{l}838,90 \\
\pm 26,15 \\
\end{array}$ & $\begin{array}{r}895,83 \\
\pm 30,64 * * \\
\end{array}$ \\
\hline \multicolumn{6}{|c|}{ Порожня кишка } \\
\hline Кальцій & $63,75-124,05$ & $\begin{array}{c}83,37 \\
\pm 5,25 * *\end{array}$ & $\begin{array}{l}93,31 \\
\pm 6,08\end{array}$ & $\begin{array}{c}95,13 \\
\pm 10,05\end{array}$ & $\begin{array}{l}100,10 \\
\pm 6,52 *\end{array}$ \\
\hline Фосфор & $128,06-264,95$ & $\begin{array}{c}178,03 \\
\pm 6,72 * *\end{array}$ & $\begin{array}{l}199,86 \\
\pm 8,07^{*}\end{array}$ & $\begin{array}{c}200,71 \\
\pm 8,72\end{array}$ & $\begin{array}{c}205,33 \\
\pm 7,75^{* *}\end{array}$ \\
\hline Калій & $64,51-200,06$ & $\begin{array}{l}113,49 \\
\pm 11,14\end{array}$ & $\begin{array}{l}130,62 \\
\pm 13,34\end{array}$ & $\begin{array}{l}128,30 \\
\pm 14,33\end{array}$ & $\begin{array}{l}144,10 \\
\pm 11,52\end{array}$ \\
\hline Натрій & $113,97-376,71$ & $\begin{array}{c}203,97 \\
\pm 19,57 * *\end{array}$ & $\begin{array}{l}-243,63 \\
\pm 16,53\end{array}$ & $\begin{array}{l}245,66 \\
\pm 10,44\end{array}$ & $\begin{array}{c}273,94 \\
\pm 16,52 * *\end{array}$ \\
\hline Залізо & $396,53-793,05$ & $\begin{array}{c}594,54 \\
\pm 27,16 * * *\end{array}$ & $\begin{array}{c}647,87 \\
\pm 26,80^{*}\end{array}$ & $\begin{array}{l}640,65 \\
\pm 24,66\end{array}$ & $\begin{array}{c}672,84 \\
\pm 26,09 * *\end{array}$ \\
\hline \multicolumn{6}{|c|}{ Клубова кишка } \\
\hline Кальцій & $40,69-81,26$ & $\begin{array}{c}53,83 \\
\pm 3,05^{* * *}\end{array}$ & $\begin{array}{c}62,09 \\
\pm 2,43^{*}\end{array}$ & $\begin{array}{c}62,41 \\
\pm 2,65^{*}\end{array}$ & $\begin{array}{c}66,69 \\
\pm 2,25^{*}\end{array}$ \\
\hline Фосфор & $36,82-76,10$ & $\begin{array}{c}52,32 \\
\pm 7,28 * * *\end{array}$ & $\begin{array}{l}57,36 \\
\pm 7,62\end{array}$ & $\begin{array}{l}57,24 \\
\pm 8,94\end{array}$ & $\begin{array}{l}61,63 \\
\pm 9,99\end{array}$ \\
\hline Калій & $86,02-284,16$ & $\begin{array}{c}149,20 \\
\pm 12,20 *\end{array}$ & $\begin{array}{l}173,46 \\
\pm 6,38\end{array}$ & $\begin{array}{l}178,42 \\
\pm 9,22\end{array}$ & $\begin{array}{c}199,32 \\
\pm 8,12 * *\end{array}$ \\
\hline Натрій & $77,86-308,41$ & $\begin{array}{c}163,09 \\
\pm 13,05^{*}\end{array}$ & $\begin{array}{l}192,37 \\
\pm 18,27\end{array}$ & $\begin{array}{l}193,39 \\
\pm 11,74\end{array}$ & $\begin{array}{c}219,56 \\
\pm 13,48^{* *}\end{array}$ \\
\hline Залізо & $510,61-867,92$ & $\begin{array}{c}657,10 \\
\pm 24,71 * *\end{array}$ & $\begin{array}{r}708,04 \\
\pm 34,39\end{array}$ & $\begin{array}{l}688,53 \\
\pm 25,28\end{array}$ & $\begin{array}{c}738,07 \\
\pm 26,51^{*}\end{array}$ \\
\hline
\end{tabular}

Примітка: одиниці виміру вмісту Са, Р, К, $\mathrm{Na}$ - ммоль/л, $\mathrm{Fe}-$ мкммоль/л, ${ }^{*} \mathrm{p} \leq 0,05, * * \mathrm{p} \leq 0,01, * * * \mathrm{p} \leq 0,0001-$ piзниці вірогідності між показниками контрольної та дослідних груп у різних відділах шлунково-кишкового тракту. 


\section{СІЛЬСЬКЕ ГОСПОДАРСТВО. ТВАРИННИЦТВО}

Порівнюючи концентрацію досліджуваних елементів у хімусі порожньої кишки з клубовою, установлено зменшення кальцію, фосфору та натрію на 35,45\% $\% \leq 0,001), 70,61 \%(\mathrm{p} \leq 0,001)$ i $20,04 \%$ ( $\leq 0,05)$, а калію збільшилося на $31,46 \%$ $(\mathrm{p} \leq 0,05)$. Характерно, що вміст кальцію знижується за просторовим інгредієнтом: шлунок $\rightarrow$ порожня кишка $\rightarrow$ клубова кишка. У цілому в тонкому кишечнику, порівнюючи зі шлунком, інтенсивність процесів мінерального травлення найбільш виражена. Щодо змін кількості мінеральних елементів у хімусі шлунково-кишкового тракту в період голодної проби й травлення спожитого корму поросятами контрольної групи, то чітко простежуються такі особливості: по-перше, максимальну концентрацію досліджуваних елементів виявлено на 2-гу год. після годівлі, через 4 год. вона знижується в 1,5 разу; по-друге, досліджувані показники голодної проби завжди менші, ніж після двогодинного інтервалу; по-третє, порівнюючи динаміку вмісту досліджуваних елементів хімусу в поросят контрольної та дослідницьких груп установлено аналогічну закономірність.

\section{3. Середньообовий баланс мінеральних елементів в організмі поросят, $M \pm m, n=4$}

\begin{tabular}{|c|c|c|c|c|c|c|c|}
\hline \multirow[t]{2}{*}{$\begin{array}{c}\text { Групи } \\
\text { тварин }\end{array}$} & \multirow{2}{*}{$\begin{array}{c}\text { Прий- } \\
\text { нято, } \\
\text { Г }\end{array}$} & \multirow{2}{*}{$\begin{array}{c}\text { Виді- } \\
\text { лено } \\
\text { з калом, г }\end{array}$} & \multirow{2}{*}{$\begin{array}{c}\text { Всмок- } \\
\text { тано, } \\
\text { г }\end{array}$} & \multirow{2}{*}{$\begin{array}{c}\text { Виділено } \\
3 \text { сечею, } \\
\text { г }\end{array}$} & \multirow[t]{2}{*}{$\begin{array}{c}\text { Засвоєно, } \\
\Gamma\end{array}$} & \multicolumn{2}{|c|}{$\begin{array}{c}\text { Коєфіціенти засвоєння } \\
\text { елементів, \% }\end{array}$} \\
\hline & & & & & & прийнятих & всмоктаних \\
\hline \multicolumn{8}{|c|}{ Кальцій } \\
\hline Контр. & 8,82 & $\begin{array}{c}3,53 \\
\pm 0,09\end{array}$ & $\begin{array}{c}5,29 \\
\pm 0,09\end{array}$ & $\begin{array}{c}0,71 \\
\pm 0,14\end{array}$ & $\begin{array}{c}4,58 \\
\pm 0,23\end{array}$ & $\begin{array}{l}51,93 \\
\pm 2,56\end{array}$ & $\begin{array}{l}86,60 \\
\pm 2,92\end{array}$ \\
\hline 1 & 8,93 & $\begin{array}{c}3,21 \\
\pm 0,13\end{array}$ & $\begin{array}{c}5,72 \\
\pm 0,013 * *\end{array}$ & $\begin{array}{c}0,86 \\
\pm 0,36\end{array}$ & $\begin{array}{c}4,85 \\
\pm 0,23\end{array}$ & $\begin{array}{l}54,35 \\
\pm 2,59\end{array}$ & $\begin{array}{l}84,99 \\
\pm 6,01\end{array}$ \\
\hline 2 & 9,00 & $\begin{array}{c}3,64 \\
\pm 0,20 \\
\end{array}$ & $\begin{array}{c}5,59 \\
\pm 0,08^{*}\end{array}$ & $\begin{array}{c}0,49 \\
\pm 0,05 \\
\end{array}$ & $\begin{array}{c}5,11 \\
\pm 0,13 \\
\end{array}$ & $\begin{array}{l}56,74 \\
\pm 1,43 \\
\end{array}$ & $\begin{array}{l}91,29 \\
\pm 1,00 \\
\end{array}$ \\
\hline \multicolumn{8}{|c|}{ Фосфор } \\
\hline Контр. & 8,31 & $\begin{array}{c}3,51 \\
\pm 0,16 \\
\end{array}$ & $\begin{array}{c}4,80 \\
\pm 0,16 \\
\end{array}$ & $\begin{array}{c}0,46 \\
\pm 0,10 \\
\end{array}$ & $\begin{array}{c}4,34 \\
\pm 0,16 \\
\end{array}$ & $\begin{array}{l}52,26 \\
\pm 1,93 \\
\end{array}$ & $\begin{array}{r}90,43 \\
\pm 1,94 \\
\end{array}$ \\
\hline 1 & 8,22 & $\begin{array}{c}3,23 \\
\pm 0,24\end{array}$ & $\begin{array}{r}4,99 \\
\pm 0,24\end{array}$ & $\begin{array}{c}0,44 \\
\pm 0,21\end{array}$ & $\begin{array}{c}4,55 \\
\pm 0,39\end{array}$ & $\begin{array}{l}55,31 \\
\pm 4,78\end{array}$ & $\begin{array}{l}91,09 \\
\pm 4,63\end{array}$ \\
\hline 2 & 8,29 & $\begin{array}{c}2,93 \\
\pm 0,05 * * * \\
\end{array}$ & $\begin{array}{c}5,36 \\
\pm 0,05 * * \\
\end{array}$ & $\begin{array}{c}0,57 \\
\pm 0,14 \\
\end{array}$ & $\begin{array}{c}4,79 \\
\pm 0,15^{*} \\
\end{array}$ & $\begin{array}{l}57,78 \\
\pm 2,09 \\
\end{array}$ & $\begin{array}{r}89,30 \\
\pm 2,68 \\
\end{array}$ \\
\hline \multicolumn{8}{|c|}{ Калій } \\
\hline Контр. & 6,20 & $\begin{array}{c}2,81 \\
\pm 0,24\end{array}$ & $\begin{array}{c}3,39 \\
\pm 0,24\end{array}$ & $\begin{array}{c}1,15 \\
\pm 0,04\end{array}$ & $\begin{array}{c}2,24 \\
\pm 0,28\end{array}$ & $\begin{array}{l}36,18 \\
\pm 4,51\end{array}$ & $\begin{array}{l}66,01 \\
\pm 3,50\end{array}$ \\
\hline 1 & 7,25 & $\begin{array}{c}2,63 \\
\pm 0,20\end{array}$ & $\begin{array}{c}4,65 \\
\pm 0,20 * * *\end{array}$ & $\begin{array}{c}1,15 \\
\pm 0,16\end{array}$ & $\begin{array}{c}3,47 \\
\pm 0,22 * *\end{array}$ & $\begin{array}{l}47,91 \\
\pm 3,00\end{array}$ & $\begin{array}{l}75,12 \\
\pm 3,35\end{array}$ \\
\hline 2 & 7,22 & $\begin{array}{c}2,75 \\
\pm 0,08 \\
\end{array}$ & $\begin{array}{c}4,47 \\
\pm 0,08 * * \\
\end{array}$ & $\begin{array}{c}1,14 \\
\pm 0,01\end{array}$ & $\begin{array}{c}3,34 \\
\pm 0,08 * * \\
\end{array}$ & $\begin{array}{l}46,21 \\
\pm 1,18 \\
\end{array}$ & $\begin{array}{l}74,58 \\
\pm 0,67 \\
\end{array}$ \\
\hline \multicolumn{8}{|c|}{ Натрій } \\
\hline Контр. & 2,71 & $\begin{array}{c}1,44 \\
\pm 0,07\end{array}$ & $\begin{array}{c}1,27 \\
\pm 0,07 \\
\end{array}$ & $\begin{array}{c}0,16 \\
\pm 0,02\end{array}$ & $\begin{array}{c}1,11 \\
\pm 0,06\end{array}$ & $\begin{array}{l}41,08 \\
\pm 2,34 \\
\end{array}$ & $\begin{array}{l}88,56 \\
\pm 1,02 \\
\end{array}$ \\
\hline 1 & 2,82 & $\begin{array}{c}1,43 \\
\pm 0,08 \\
\end{array}$ & $\begin{array}{r}1,39 \\
\pm 0,08 \\
\end{array}$ & $\begin{array}{c}0,16 \\
\pm 0,02 \\
\end{array}$ & $\begin{array}{c}1,23 \\
\pm 0,06 \\
\end{array}$ & $\begin{array}{l}43,74 \\
\pm 2,02 \\
\end{array}$ & $\begin{array}{l}88,77 \\
\pm 1,30 \\
\end{array}$ \\
\hline 2 & 2,98 & $\begin{array}{c}1,46 \\
\pm 0,01 \\
\end{array}$ & $\begin{array}{c}1,52 \\
\pm 0,01 * \\
\end{array}$ & $\begin{array}{c}0,16 \\
\pm 0,01 \\
\end{array}$ & $\begin{array}{c}1,35 \\
\pm 0,02 * * \\
\end{array}$ & $\begin{array}{c}45,41 \\
\pm 0,7 \\
\end{array}$ & $\begin{array}{l}89,23 \\
\pm 1,05 \\
\end{array}$ \\
\hline \multicolumn{8}{|c|}{ Залізо } \\
\hline Контр. & 179,39 & $\begin{array}{l}50,22 \\
\pm 1,14 \\
\end{array}$ & $\begin{array}{l}129,17 \\
\pm 1,14\end{array}$ & $\begin{array}{l}19,55 \\
\pm 2,77 \\
\end{array}$ & $\begin{array}{l}109,62 \\
\pm 3,65\end{array}$ & $\begin{array}{l}61,11 \\
\pm 2,03 \\
\end{array}$ & $\begin{array}{l}84,85 \\
\pm 2,24 \\
\end{array}$ \\
\hline 1 & 178,55 & $\begin{array}{l}49,50 \\
\pm 1,09\end{array}$ & $\begin{array}{l}129,05 \\
\pm 1,09\end{array}$ & $\begin{array}{c}15,21 \\
\pm 0,61 *\end{array}$ & $\begin{array}{l}113,84 \\
\pm 1,29\end{array}$ & $\begin{array}{l}63,77 \\
\pm 0,74\end{array}$ & $\begin{array}{l}88,21 \\
\pm 0,48\end{array}$ \\
\hline 2 & 178,42 & $\begin{array}{l}50,66 \\
\pm 0,43 \\
\end{array}$ & $\begin{array}{l}127,76 \\
\pm 0,43\end{array}$ & $\begin{array}{l}15,54 \\
\pm 0,80 \\
\end{array}$ & $\begin{array}{c}112,22 \\
\pm 1,08\end{array}$ & $\begin{array}{c}62,89 \\
\pm 0,6 \\
\end{array}$ & $\begin{array}{l}81,83 \\
\pm 0,65 \\
\end{array}$ \\
\hline
\end{tabular}

Примітка: одиниці виміру заліза, мг * $\mathrm{p} \leq 0,05, * * \mathrm{p} \leq 0,01, * * * \mathrm{p} \leq 0,0001-$ різниця вірогідності між показниками контрольної та дослідних груп. 


\section{СІЛЬСЬКЕ ГОСПОДАРСТВО. ТВАРИННИЦТВО}

У першій та другій групах після годівлі тварин (інтервал через 2-4 год.) зберігалася висока концентрація мінералів, хоча через 6 год. та у період голодної проби різниці з контролем не виявлено. За різні терміни взяття проб найбільшу кількість мінералів виявлено в основному у хімусі піддослідних поросят третьої групи.

Зазначені особливості вмісту мінеральних елементів у травному тракті доповнюють також і рівень процесів обміну їх під впливом різних композиційних кормових добавок у раціоні поросят. За сумарними показниками концентрації мінеральних речовин у піддослідних тварин різних груп установлено істотні відмінності. 3'ясовано, що в процесі травлення (залежно від складу кормової добавки та співвідношення між iіi компонентами) змінюється й концентрація досліджуваних мінеральних речовин у хімусі.

Незважаючи на те, що в раціоні поросят першої дослідної групи було 2 \% СМК, усе ж за кількість мінеральних речовин у хімусі (порівняно 3 другою) істотної різниці не виявлено. Однак під дією комплексної кормової добавки, яку отримували тварини третьої дослідної групи, простежується достовірне збільшення концентрації мінералів у досліджуваних відділах шлунково-кишкового тракту. Водночас не встановлено значних змін за кількістю кальцію та фосфору в хімусі шлунка, калію - у порожній кишці та фосфору - в клубовій.

Динаміка балансу кальцію, фосфору, калію, натрію, заліза в залежності від згодовування кормових добавок у раціоні поросят представлена в таблиці 3.

\section{БІБЛІОГРАФІЯ}

1. Бакеева E. H. Физиологические основы кормления свиней / Е. Н. Бакеева - К. : Госсельхозиздат УССР, 1963. - $114 \mathrm{c.}$

2. Богданов Г. А. Кормление сельскохозяйственных животных / Г. А. Богданов. - М. : Агропромиздат, 1990. - 620 с.

3. Буркат В. П., Бегма Л. А., Бегма А. А. Новые препараты, созданные на основе эхинацеи пурпурной, и их использование в животноводстве. - Изучение и использование эхинацеи / Материалы Междунар. науч. конф. - Полтава : Верстка, 1998. - С. 105-107.

4. Водянников В., Соломатин В., Водянников И. Природный бишофит повышает продуктивность // Животноводство России. Раздел «Свиноводство». - 2007. - №1. - С. 33-34.

5. Деклараційний патент на винахід. Україна, А23К1/00, А23К1/12. Спосіб приготування кормової добавки / Коваленко В. Ф., Гришко В. В.,
У цілому кількість мінеральних елементів у кормах тварин дослідних і контрольної груп відрізнялася несуттєво.

Всмоктування кальцію, фосфору, калію та натрію у тварин другої дослідної групи було кращим і статистично вірогідним порівняно $з$ контролем.

Виділення досліджуваних елементів із калом i сечею було майже однаковим, а у поросят другої дослідної групи виділялося фосфору достовірно менше 3 калом, аніж у контрольній. Кількість виділеного заліза 3 сечею у першій дослідній групі було менше на 4 мг ( $\leq \leq 0,05)$.

Рівень мінералів у раціоні виявив вплив на краще засвоєння фосфору, калію, та натрію. Порівняно з контролем в організмі поросят другої дослідної групи використання фосфору та натрію було достовірно більше - 4,79 г $(\mathrm{p} \leq 0,05)$, 3,34 г достовірно більше $(\mathrm{p} \leq 0,01)$ відповідно. Аналогічна закономірність відмічена по кількості калію у першій дослідній групі.

\section{Висновки:}

1. Показники сухої речовини та концентрації мінеральних елементів у хімусі різних відділів шлунково-кишкового тракту поросят не однакові, хоча здатні до коливання, однак у тонкому кишечнику (порівняно зі шлунком) мінеральний обмін більш виражений.

2. Рівень співвідношення інгредієнтів кормової добавки впливає на вміст сухої речовини та мінеральних елементів у хімусі досліджуваних ділянок травного апарату й, відповідно, не виключена можливість стимулювання фізіологічних процесів в організмі поросят.

Рибалко В. П. [та ін.]; заявник та патентоотримувач Інститут свинарства ім. О. В. Квасницького. - №31475A; пріоритет 15.09.98; опубл. 15.12.00, Бюл. № 7 (II).

6. Деклараційний патент на корисну модель. Україна, А23К1/00. Комплексний біологічно активний препарат / Коваленко В. Ф., Мироненко О. І., Яценко Л. І. [та ін.]; заявник та патентоотримувач Інститут свинарства ім. О. В. Квасницького. - 7699, пріоритет 16.08.04, опубл. 15.07 .05 , Бюл. № 7.

7. Ібатуллін I. I. Ефективність використання лізин-протеїнової кормової добавки - ліпрот при відгодівлі молодняку свиней / I. I. Ібатуллін, М. Я. Кривенко // Науковий вісник НАУ: Зб. наук. праць. - К., 1998. - Вип. 3. - С. 78-81.

8. Изучение минерального обмена у сельскохозяйственных животных: методические указания / [Подготовили С. Г. Кузнецов, Б. Д. Каль- 


\section{СІЛЬСЬКЕ ГОСПОДАРСТВО. ТВАРИННИЦТВО}

ницкий]. - Боровск: ВНИИФБиП с.-х. животных. - 1983. - 83 с.

9. Изучить пластовые воды нефтяных месторождений на шести участках Полтавской области, определить перспективу лечебного применения и дать лечебную оценку / Заключительный отчет о научно-исследовательской работе Одесского НИИ курортологии и медицинской реабилитации. - Одесса, 1991. - 20 с.

10. Кальницкий Б. Д. Минеральное питание свиней // Сельское хозяйство за рубежом. - 1980. - №9. - С. 33-34.

11. Кваснищъкий A. В. Физиология пищеварения у свиней. - М. : Сельхозгиз, 1951. - 231 с.

12. Комплексное (физиологическое и зоотехническое) изучение процессов питания у свиней: методические рекомендации / [составлены Е. 3. Ткачевым, И. И. Мошкутело]. - М. : ВАСХНИЛ, 1988. - 83 с.

13. Кулик М.Ф., Засуха Т. В., Величко І. М. Традиційні і нетрадиційні мінерали у тваринництві. - К. : Сільгоспосвіта, 1995. - С. 21-22; 107115.

14. Мельник Ю. Ф., Рибалко В. П. Рекомендації з використання комплексної кормової добавки «ЛІПРОТ» у годівлі свиней. - Полтава - Горлівка, 2003. - $16 \mathrm{c}$.

15. Морозов И.А., Льсиков Ю. А., Питран Б. В. [и др.]. Всасывание и секреция в тонкой кишке. - М. : Медицина, 1988. - 224 с.

16. Ноздрін М. Т., Данилко Л. М. Біоконверсія мінералізованих (пластових) вод для потреб свинарства: напрямки досліджень i здобутки Полтавського державного сільськогосподарського інституту // Вісник Полт. держ. с.-г. ін-ту. 2001. - №4. - C. 66-68.

17. Писаренко П. В. Мінералізована (пластова) вода: використання в землеробстві. - Полтава : Камелот, 1999. - 126 с.

18. Самородов В. Н., Лебединский И. С., Ищенко Н. В. Изучение видов рода эхинацеи как лечебно-кормовых растений // Проблеми лікарського рослинництва. - Тези доп. Міжнарод. наук.практ. конф. 3 нагоди 80-річчя Інстит. лікарських рослин УААН (3-5 липня 1996 р., м. Лубни). Полтава, 1996. - С. 281-283.

19. Синещуеков А. Д. Биология питания сельскохозяйственных животных: Биол. основы рацион. использ. кормов. - М. : Колос, 1965. - 399 с.

20. Ткачев E. 3. Физиология питания свиней. М. : Колос, 1981. - 239 с.

21. Физиология и биохимия пищеварения животных и человека / В. К. Рыбальченко, Т. В. Береговая, М. Ю. Клевец [и др.]; Под ред. В. К. Рыбальченка. - К. : Фитосоциоцентр, 2002. -365 c. 